\title{
Trends and Policy Implications of Data Envelopment Analysis Method in the Process of Environment Sustainable Development
}

\author{
Xiao Liu ${ }^{1}$, Jun Miao ${ }^{1}$, Houxue Xia ${ }^{2}$, Anqi Qiu ${ }^{1}$, Jin Chen ${ }^{1,3}$ \\ ${ }^{1}$ College of Economics and Management, Huaiyin Normal University, 71 Jiaotong Avenue, Huaian 223001, \\ China \\ ${ }^{2}$ Business School, National University of Singapore, 15Kent Ridge Drive, 119245, Singapore \\ ${ }^{3}$ College of Management, China University of Mining and Technology,1 Daxue Avenue, Xuzhou 221116, China \\ Correspondence: Xiao Liu, College of Economics and Management, Huaiyin Normal University, 71 Jiaotong \\ Avenue, Huaian 223001, China.
}

Received: August 19, 2020

Accepted: September 22, 2020

Online Published: October 21, 2020

doi:10.5539/ibr.v13n11p25

URL: https://doi.org/10.5539/ibr.v13n11p25

\begin{abstract}
Effective performance evaluation for sustainable development is significantly important for determining the dynamic harmony and balance of environment, economy and society. Data envelopment analysis (DEA) has been widely applied in the field of sustainability evaluation modeling in recent years. In this study, the application of DEA in sustainable development field research is systematically reviewed. The entire framework of DEA in sustainable development research is constructed, and the characteristics of the research works are summarized. The principal characters used in previous studies are identified and compared, and then the methodological framework for deriving sustainable development indicators is introduced. Finally, from the two aspects of method and experience, this study summarizes some beneficial points of model selection. Based on this, the expectation of DEA method in the process of sustainable development is further discussed.
\end{abstract}

Keywords: Data envelopment analysis (DEA), sustainable development, efficiency, environmental performance

\section{Introduction}

Since the World War II, emissions generated by human activities have already altered climate change. Biologists find that, over the past fifty years, the increasingly heavy loss of biodiversity has led to the earth's a quarter of largest incidents of life destruction. In 1992, on the United Nations Earth Summit held in Rio de Janeiro, sustainable development (SD) was formally proposed as one of the most urgent subjects for international policy.

SD is a widely used concept and it has become increasingly popular since the famous Brundtland Report, in which SD was defined as "development that meets current needs without prejudicing the ability of progeniture succeeding era to meet their own needs" (Becker \& Mlligan, 1997). This definition took a comprehensive consideration from three aspects simultaneously: natural resources are recognized as the limited availability; intergenerational equity need is accepted; several social and spatial issues are summarized as intergenerational equity (Dong et al., 2016). As such, SD integrates understanding and acting on the complex interrelationships that exist among the environment, the economy, and society. This is not a balancing act or playing one issue against the other, but an acknowledgement of the correlation dependence character of these three pillars. Despite of the impressive amount of related scientific literature, when it comes to empirical research, SD remains a vague and elusive terminology.

Among the extensive SD modeling techniques, many studies reported that data envelopment analysis (DEA), a non-parametric efficiency evaluation method, is an excellent approach to examining the sustainability performance of decision-making units (DMUs). Specifically, Callens and Tyteca (1999) briefly phrased why DEA can be used to assess sustainability, and pointed out that one of the necessary and inadequate steps to achieve sustainability was the efficiency of economic, social and environmental resources. Zhou et al. (2008) pointed that DEA is a special multi-criteria decision analysis (MCDA) method, which aims at evaluating the relative efficiency of all DMUs, rather than choosing specific action paths as traditional decision analysis does. However, with the increasing application of DEA in SD research, it is timely and meaningful to review and summarize the findings in this field. The main objective of this study is to fill this gap. 


\section{Basic DEA Model}

DEA model was firstly proposed by Charnes et al. (1978) to measure the efficiency and productivity of a group of peer DMUs. DEA efficiency is the ratio of the weighted sums of the outputs and the inputs, under the premise that efficiency unable to exceed the value of 1 . As such, the DEA efficiency of a certain DMU will reduce when outputs decrease and/or inputs increase, and vice versa. Under the basic DEA framework, given a set of $K$ units $\left(\mathrm{DMU}_{1}, \mathrm{DMU}_{2}, \ldots, \mathrm{DMU}_{\mathrm{K}}\right)$, each producing $M$ outputs from a set of $N$ inputs. A certain unit $\mathrm{DMU}_{\mathrm{k}}$ consumes $x_{n k} \geq 0$ of input $n$ to produce $y_{m k} \geq 0$ of output $m$. This problem can be further transformed into the famous CCR model as follows:

$$
\begin{array}{ll}
\max & \sum_{m=1}^{M} u_{m} y_{m 0} \\
\text { s.t. } & \sum_{m=1}^{M} u_{m} y_{m k}-\sum_{n=1}^{N} v_{n} x_{n k} \leq 0, \quad k=1,2, \ldots, K, \\
& \sum_{n=1}^{N} v_{n} x_{n 0}=1, \\
& u_{m}, v_{n} \geq 0, m=1,2, \ldots, M ; \\
& n=1,2, \ldots, N
\end{array}
$$

Where $u_{m}$ and $v_{n}$ are two vectors of weight that $\mathrm{DMU}_{0}$ uses to measure the relative importance of the consumed and the produced factors. Despite its liner form, studies usually use CCR in envelopment form to calculate the efficiency score (Zhu, 1996). In fact, the envelopment form is the dual model of (1), as follows:

$$
\begin{array}{ll}
\min & \theta \\
\text { s.t. } & \sum_{m=1}^{M} y_{m k} \lambda_{k} \geq y_{m 0}, \quad \mathrm{~m}=1,2, \ldots, \mathrm{M}, \\
& \sum_{n=1}^{N} x_{n k} \lambda_{k} \leq \theta x_{n 0}, n=1,2, \ldots, N, \\
& \lambda_{k} \geq 0, \mathrm{k}=1,2, \ldots, \mathrm{K} .
\end{array}
$$

Further considering the constraint set in the model (2):

$$
\begin{gathered}
T=\left\{(x, y): \sum_{k=1}^{K} x_{n k} z_{k} \leq x_{n}, \quad n=1,2, \ldots, N,\right. \\
\sum_{k=1}^{K} y_{m k} z_{k} \geq y_{m}, \quad m=1,2, \ldots, M, \\
\left.z_{k} \geq 0, k=1,2, \ldots, K\right\},
\end{gathered}
$$

Where $x=\left(x_{1}, x_{2}, \ldots, x_{n}\right)$ is the input vector, $y=\left(y_{1}, y_{2}, \ldots, y_{m}\right)$ is the output vector, $z_{k}$ is a set of intensity variables representing the weighting of each observed $\mathrm{DMU}_{\mathrm{k}}$ in the composition of the efficient frontier, and $T$ is defined as the reference technology.

As was described by Sarkis and Talluri (2011), DEA has been used widely in various fields in the past decade and there are a large number of extensions. The representative studies listed in Table 1 have been collected. In the following sections, we mainly describe the characteristics of previous studies from the aspects of research type, method and application fields. 
Table 1. Representative studies of DEA method in sustainable development field

\begin{tabular}{|c|c|c|c|c|c|c|c|c|}
\hline \multirow{3}{*}{ Publication } & \multirow{3}{*}{$\begin{array}{l}\text { Type } \\
\text { of } \\
\text { study }\end{array}$} & \multicolumn{6}{|c|}{ Methodological aspect } & \multirow{3}{*}{ Application scheme } \\
\hline & & \multicolumn{3}{|c|}{$\begin{array}{c}\text { Production possibility } \\
\text { set }\end{array}$} & \multirow{2}{*}{$\begin{array}{c}\text { Efficiency } \\
\text { measure }\end{array}$} & \multirow{2}{*}{$\begin{array}{c}\text { Model } \\
\text { extension }\end{array}$} & \multirow{2}{*}{$\begin{array}{c}\text { Joint } \\
\text { with } \\
\text { others }\end{array}$} & \\
\hline & & Input & Output & $R T S$ & & & & \\
\hline $\begin{array}{l}\text { Abay et al. } \\
(2004)\end{array}$ & A & $S$ & W & $\mathrm{C}$ & $\mathrm{R}$ & MPI & EM & $\begin{array}{l}\text { Assessment of } \\
\text { sustainability at farm level }\end{array}$ \\
\hline $\begin{array}{l}\text { Aldeseit } \\
(2013)\end{array}$ & A & $S$ & $S$ & $\mathrm{C}+\mathrm{V}$ & $\mathrm{R}$ & - & - & $\begin{array}{l}\text { Farms sustainability } \\
\text { assessment }\end{array}$ \\
\hline $\begin{array}{l}\text { André et al. } \\
\text { (2010) }\end{array}$ & $\mathrm{T}+\mathrm{A}$ & $\mathrm{S}$ & $S$ & $\mathrm{C}$ & $\mathrm{R}$ & - & MCDM & $\begin{array}{l}\text { Agricultural economics and } \\
\text { sustainability }\end{array}$ \\
\hline $\begin{array}{l}\text { Arabi et al. } \\
\text { (2014) }\end{array}$ & $\mathrm{T}+\mathrm{A}$ & $S$ & W & $\mathrm{C}$ & SB & ML & - & $\begin{array}{l}\text { Eco-efficiency } \\
\text { measurement }\end{array}$ \\
\hline $\begin{array}{l}\text { Gutierrez et al. } \\
\text { (2009) }\end{array}$ & $\mathrm{T}+\mathrm{A}$ & $S$ & $S$ & $\mathrm{~V}$ & SB & - & LCA & $\begin{array}{l}\text { Eco-efficiency of electric } \\
\text { and electronic appliances }\end{array}$ \\
\hline $\begin{array}{c}\text { Battese \& } \\
\text { Coelli (1995) }\end{array}$ & $\mathrm{T}$ & $S$ & $\mathrm{~S}$ & $\mathrm{C}$ & $\mathrm{R}$ & - & SFA & $\begin{array}{l}\text { Agricultural sustainability } \\
\text { measurement }\end{array}$ \\
\hline $\begin{array}{l}\text { Donghyun \& } \\
\text { Almas (2010) }\end{array}$ & $\mathrm{T}+\mathrm{A}$ & S & W & $\mathrm{C}$ & DDF & ML & - & $\begin{array}{l}\text { Environmentally sensitive } \\
\text { productivity growth } \\
\text { assessment }\end{array}$ \\
\hline $\begin{array}{l}\text { Dong et al. } \\
\text { (2016) }\end{array}$ & $\mathrm{T}+\mathrm{A}$ & $S$ & S & $\mathrm{C}$ & $\mathrm{R}$ & - & LCA & $\begin{array}{l}\text { Assessing sustainability in } \\
\text { agricultural sectors }\end{array}$ \\
\hline $\begin{array}{l}\text { Egilmez \& } \\
\text { Park (2014) }\end{array}$ & $\mathrm{T}+\mathrm{A}$ & $S$ & $\mathrm{~S}$ & $\mathrm{~V}$ & $\mathrm{R}$ & SA & LCA & $\begin{array}{l}\text { Sustainability measurement } \\
\text { of manufacturing sector }\end{array}$ \\
\hline $\begin{array}{l}\text { Egilmez et al. } \\
\quad(2014)\end{array}$ & A & $S$ & W & $\mathrm{C}$ & $\mathrm{R}$ & - & LCA & $\begin{array}{l}\text { Sustainability assessment of } \\
\text { supply chain }\end{array}$ \\
\hline $\begin{array}{l}\text { Ewert et al. } \\
\quad(2005)\end{array}$ & A & $\mathrm{S}$ & W & $\mathrm{V}$ & $\mathrm{R}$ & ML, SA & - & $\begin{array}{l}\text { Measurement of economic, } \\
\text { environmental and social } \\
\text { sustainability in agricultural }\end{array}$ \\
\hline $\begin{array}{l}\text { Gerdessen \& } \\
\text { Pascucci } \\
(2013)\end{array}$ & A & S & S & $\mathrm{C}+\mathrm{V}$ & $\mathrm{R}$ & - & - & $\begin{array}{l}\text { Assessment of } \\
\text { sustainability at farm level }\end{array}$ \\
\hline $\begin{array}{l}\text { Gomes et al. } \\
\text { (2009) }\end{array}$ & $\mathrm{T}$ & $\begin{array}{l}\text { CCR e } \\
\text { undesir } \\
\text { conside }\end{array}$ & $\begin{array}{l}\text { ensions w } \\
\text { ble output } \\
\text { ed }\end{array}$ & & NR & - & - & $\begin{array}{l}\text { Assessment of } \\
\text { sustainability at farm level }\end{array}$ \\
\hline $\begin{array}{c}\text { Gutierrez \& } \\
\text { Lozano (2009) }\end{array}$ & $\mathrm{T}+\mathrm{A}$ & S & S & $\mathrm{C}+\mathrm{V}$ & $\mathrm{R}$ & - & - & $\begin{array}{l}\text { Sustainability measurement } \\
\text { of manufacturing sector }\end{array}$ \\
\hline $\begin{array}{l}\text { Hoang \& } \\
\text { Alauddun } \\
\text { (2012) }\end{array}$ & $\mathrm{T}+\mathrm{A}$ & S & S & $\mathrm{C}+\mathrm{V}$ & $\mathrm{R}$ & - & - & Agricultural sustainability \\
\hline $\begin{array}{l}\text { Houshyar et al. } \\
\qquad(2012)\end{array}$ & $\mathrm{T}+\mathrm{A}$ & $S$ & $\mathrm{~S}, \mathrm{~W}$ & $\mathrm{C}$ & SB & MPI & $\begin{array}{c}\text { Multi } \\
\text { fuzzy } \\
\text { modeling }\end{array}$ & $\begin{array}{l}\text { Sustainable and efficient } \\
\text { energy consumption of corn } \\
\text { production }\end{array}$ \\
\hline $\begin{array}{l}\text { Iribarren \& } \\
\text { Rowe (2013) }\end{array}$ & $\mathrm{T}+\mathrm{A}$ & $S$ & W & $\mathrm{C}$ & SB & - & LCA & $\begin{array}{l}\text { Sustainability of product } \\
\text { systems assessment }\end{array}$ \\
\hline $\begin{array}{l}\text { Juo et al. } \\
(2015)\end{array}$ & $\mathrm{T}+\mathrm{A}$ & $S$ & W & V & NR & ML & - & $\begin{array}{l}\text { Productivity estimation } \\
\text { with pollutions considered }\end{array}$ \\
\hline $\begin{array}{l}\text { Khodakarami } \\
\text { et al. }(2015)\end{array}$ & $\mathrm{T}+\mathrm{A}$ & $S$ & W & V & NR, SB & MPI & - & $\begin{array}{l}\text { Assessment of } \\
\text { sustainability supply chain }\end{array}$ \\
\hline $\begin{array}{l}\text { Korhonen \& } \\
\text { Luptacik } \\
\text { (2004) }\end{array}$ & $\mathrm{T}+\mathrm{A}$ & $\begin{array}{l}\text { CCR e } \\
\text { undesir } \\
\text { conside }\end{array}$ & $\begin{array}{l}\text { ensions w } \\
\text { ble output } \\
\text { ed }\end{array}$ & & DDF & - & - & $\begin{array}{l}\text { Eco-efficiency } \\
\text { measurement }\end{array}$ \\
\hline Li (2010) & $\mathrm{T}+\mathrm{A}$ & $\mathrm{S}$ & W & $\mathrm{C}$ & DDF & PDA & - & $\begin{array}{l}\mathrm{CO} 2 \text { emission performance } \\
\text { assessment }\end{array}$ \\
\hline $\begin{array}{l}\text { Louhichi et al. } \\
\qquad(2010)\end{array}$ & $\mathrm{T}+\mathrm{A}$ & $S$ & W & $\mathrm{C}+\mathrm{V}$ & $\mathrm{R}, \mathrm{SB}$ & - & $\begin{array}{l}\text { AHP, } \\
\text { MCDM }\end{array}$ & $\begin{array}{l}\text { Measurement of economic, } \\
\text { environmental and social } \\
\text { sustainability in agricultural }\end{array}$ \\
\hline $\begin{array}{l}\text { Mahdiloo et al. } \\
\qquad(2015)\end{array}$ & $\mathrm{T}+\mathrm{A}$ & $S$ & W & $\mathrm{C}$ & $\mathrm{R}$ & MPI & MOLP & $\begin{array}{l}\text { Assessment of } \\
\text { sustainability supply chain }\end{array}$ \\
\hline $\begin{array}{l}\text { Senante et al. } \\
\quad(2014)\end{array}$ & A & S & S & V & $\mathrm{R}$ & MPI & AHP & $\begin{array}{l}\text { Sustainable performance of } \\
\text { wastewater treatment plants }\end{array}$ \\
\hline $\begin{array}{l}\text { Senante et al. } \\
\quad(2016)\end{array}$ & $\mathrm{T}+\mathrm{A}$ & S & W & V & DDF, NR & - & - & $\begin{array}{l}\text { Eco-efficiency assessment } \\
\text { of wastewater treatment } \\
\text { plants }\end{array}$ \\
\hline $\begin{array}{l}\text { Munksgaard et } \\
\text { al. (2008) }\end{array}$ & $\mathrm{T}+\mathrm{A}$ & S & $S$ & $\mathrm{C}$ & $\mathrm{R}$ & - & LCA & Sustainable consumption \\
\hline Reig-Martinez & A & S & W & $\mathrm{C}$ & $\mathrm{R}$ & - & MCDM & Assessment of \\
\hline
\end{tabular}




\begin{tabular}{|c|c|c|c|c|c|c|c|c|}
\hline et al. (2011) & & & & & & & & sustainability at farm level \\
\hline $\begin{array}{l}\text { Reinharda et } \\
\text { al. (2000) }\end{array}$ & $\mathrm{T}+\mathrm{A}$ & $\mathrm{S}$ & $\mathrm{W}$ & V & NR & SA & SFA & $\begin{array}{l}\text { Estimation of } \\
\text { comprehensive } \\
\text { environmental efficiency }\end{array}$ \\
\hline $\begin{array}{l}\text { Sueyoshi \& } \\
\text { Wang (2014) }\end{array}$ & $\mathrm{T}+\mathrm{A}$ & $\mathrm{S}$ & $\mathrm{W}$ & V & $\mathrm{R}, \mathrm{NR}$ & - & - & $\begin{array}{l}\text { Assessment of } \\
\text { sustainability supply chain }\end{array}$ \\
\hline $\begin{array}{l}\text { Sueyoshi \& } \\
\text { Yuan (2015) }\end{array}$ & $\mathrm{T}+\mathrm{A}$ & $\mathrm{S}$ & $\mathrm{W}$ & $\mathrm{C}+\mathrm{V}$ & SB & - & - & $\begin{array}{l}\text { Regional sustainability and } \\
\text { diversity }\end{array}$ \\
\hline $\begin{array}{l}\text { Sueyoshi \& } \\
\text { Goto (2015) }\end{array}$ & $\mathrm{T}+\mathrm{A}$ & $\mathrm{S}$ & $\mathrm{W}$ & $\mathrm{C}$ & $\mathrm{R}$ & MPI & - & $\begin{array}{l}\text { Environmental assessment } \\
\text { in time horizon }\end{array}$ \\
\hline $\begin{array}{l}\text { Sueyoshi \& } \\
\text { Yuan (2016) }\end{array}$ & $\mathrm{T}+\mathrm{A}$ & $\mathrm{S}$ & $\mathrm{W}$ & V & SB & - & - & $\begin{array}{l}\text { Assessment of } \\
\text { transformation marginal } \\
\text { rate among production } \\
\text { factors }\end{array}$ \\
\hline $\begin{array}{l}\text { Sueyoshi et al. } \\
\text { (2018) }\end{array}$ & $\mathrm{T}+\mathrm{A}$ & $\mathrm{S}$ & $\mathrm{W}$ & $\mathrm{C}$ & $\mathrm{R}, \mathrm{NR}$ & - & MCDM & $\begin{array}{l}\text { Sector sustainability on } \\
\text { fossil fuel power plants }\end{array}$ \\
\hline $\begin{array}{c}\text { Tatari \& } \\
\text { Kucukvar } \\
(2012)\end{array}$ & $\mathrm{T}+\mathrm{A}$ & $\mathrm{S}$ & $\mathrm{S}$ & $\mathrm{C}$ & $\mathrm{R}$ & - & LCA & $\begin{array}{l}\text { Measurement of } \\
\text { sustainability performance }\end{array}$ \\
\hline $\begin{array}{l}\text { Vandaele et al. } \\
\text { (2013) }\end{array}$ & A & $\mathrm{S}$ & $\mathrm{S}$ & $\mathrm{C}+\mathrm{V}$ & $\mathrm{R}$ & - & - & $\begin{array}{l}\text { Sustainable R\&D portfolio } \\
\text { assessment }\end{array}$ \\
\hline $\begin{array}{l}\text { Zanella et al. } \\
\qquad(2015)\end{array}$ & A & $\mathrm{S}$ & W & V & DDF & ML & - & Cities' livability \\
\hline $\begin{array}{l}\text { Zhou et al. } \\
\text { (2007) }\end{array}$ & $\mathrm{T}+\mathrm{A}$ & $\mathrm{S}$ & $\mathrm{W}$ & $\mathrm{C}$ & NR & MPI & - & $\begin{array}{l}\text { Environmental } \\
\text { sustainability measurement }\end{array}$ \\
\hline $\begin{array}{l}\text { Zhu et al., } \\
\text { (2014) }\end{array}$ & A & $\mathrm{S}$ & $\mathrm{W}$ & $\mathrm{C}$ & $\mathrm{R}$ & - & - & $\begin{array}{l}\text { Assessment of the products } \\
\text { eco-efficiency }\end{array}$ \\
\hline
\end{tabular}

Note: T: theory; A: application; S: strong-disposable; W: weak-disposable; C: constant returns to scale; V: variant returns to scale; R: radial; NR: non-radial; SB: Slacks-based; DDF: directional distance function; MPI: Malmquist productivity index; ML: Malmquist-Luenberger productivity index; PDA: production decomposition analysis; SA: sensitive analysis; LCA: life cycle analysis; AHP: analytic hierarchy process; SFA: stochastic frontier analysis; MCDM: multi-criteria decision making.

\section{Methodological Development and Issues in SD}

The methodological development and issues in SD field can be broken down into three parts: the key elements of DEA model, the extensions of DEA model and the DEA model joint with other methodologies. Furthermore, the methodological development can be characterized by the reference technology, the efficiency measurement, the preference, the super efficiency DEA model and other DEA models. The extensions of DEA model includes Malmquist productivity index (MPI), Malmquist-Luenberger productivity index (ML), production decomposition analysis (PDA) and sensitive analysis (SA). According to the review, we also find that DEA model applied in SD usually combines with other methods such as life cycle analysis (LCA), analytic hierarchy process (AHP), stochastic frontier analysis (SFA) and multi-criteria decision making (MCDM). Fig. 1 generally presents the DEA model framework and the most widely used mode types in SD studies. 


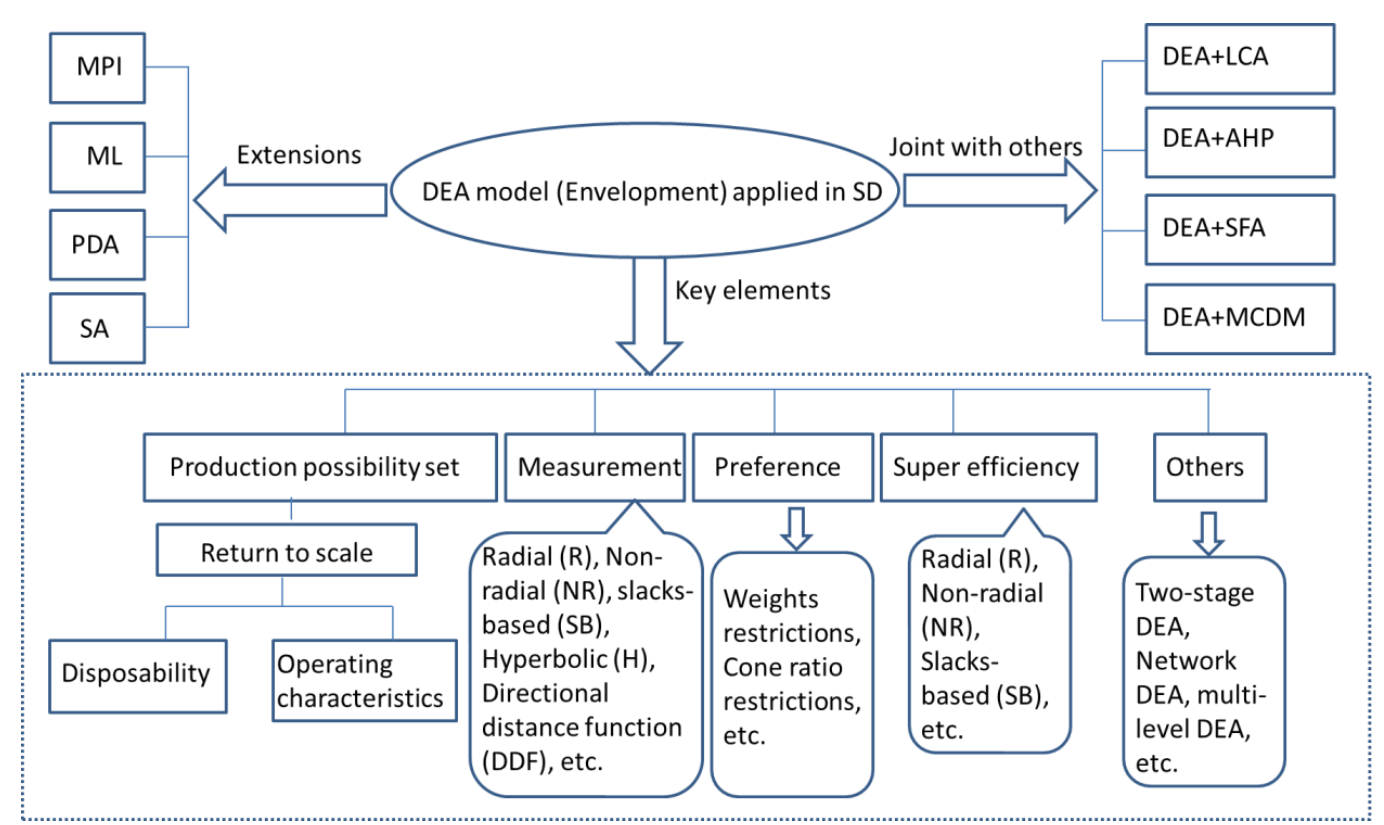

Figure 1. General framework of DEA model and methods in sustainable development studies

\subsection{Key Elements}

The methodology of DEA includes some key elements, and the specific DEA model form is determined by these key elements. Usually, the key elements applied in SD incorporate the follows: (1) production possibility set; (2) efficiency measurement; (3) preference; (4) super efficiency. The different combinations of these elements can form the various types of DEA models, with which to figure out different issues.

\subsubsection{Production Possibility Set}

Traditionally, in basic DEA model, the production possibility set satisfies that if $(x, y) \in T$ and $x^{\prime} \geq x \quad$ (or $y^{\prime} \leq y$ ) then $\left(x^{\prime}, y\right) \in T \quad\left(\right.$ or $\left.\left(x, y^{\prime}\right) \in T\right)$. Both inputs and outputs are denoted as freely or strongly disposable.

Not surprisingly, as shown in Table 1 , most representative studies that evaluate sustainability performance assume all the inputs are freely disposal. However, in the real production process, people can't avoid the undesirable outputs. For example, energy consumption pulls up the economic increasing, meanwhile, the undesirable outputs such as the emission of $\mathrm{CO}_{2}$ and $\mathrm{SO}_{2}$ are always accompanied. As such, reducing undesirable outputs would likely to be costly. Therefore, using the freely disposability production possibility set is not appropriate. In order to overcome this issue, many methods are put forward. Of which, undesirable outputs $\left(u=\left(u_{1}, u_{2}, \ldots, u_{j}\right)\right)$ weak disposability technology has been widely used (Zhou et al., 2008). The weak disposability production possibility set can be characterized as follows:

$$
\begin{gathered}
T_{e}=\left\{(x, y, u): \sum_{k=1}^{K} x_{n k} z_{k} \leq x_{n}, \quad n=1,2, \ldots, N,\right. \\
\sum_{k=1}^{K} y_{m k} z_{k} \geq y_{m}, \quad m=1,2, \ldots, M, \\
\sum_{k=1}^{K} u_{j k} z_{k}=u_{j}, j=1,2, \ldots, J \\
\left.z_{k} \geq 0, k=1,2, \ldots, K\right\},
\end{gathered}
$$

$T_{e}$ could be regarded as a more realistic production technology due to the desirable and undesirable outputs are both considered simultaneously. Similarly, the case of inputs can also be generalized (Färe et al., 2001). As such, $T_{e}$ has been greatly used in the SD field, especially in the situation like sustainability assessment, environmental performance measure, and environmental regulation impacts evaluation with undesirable pollutants consideration. This may explain why the majority of studies listed in Table 1 prefer to use $T_{e}$ as production possibility set, such as Houshyar et al. (2012), Sueyoshi and Wang (2014), Sueyoshi and Gote (2015), and 
Khodakarami et al. (2015). In these studies, the $T_{e}$ technology is more attractive because of its theoretical property advantages and the better depiction of the real production process. However, there are still some exceptions such as Egilmez et al. (2013), Senante et al. (2014) and Dong et al. (2016) which do not take undesirable outputs into consideration.

Returns to scale (RTS) is another major trait of the production possibility set. Generally, the traditional CCR-DEA model assumes the constant return to scale (CRS), however, if a constraint $\sum_{k=1}^{K} \lambda_{k}=1$ is added to $T$, the model will change to permit dealing with variable scale efficiency (VRS). As such, model (2) will change from CCR to the BCC model. Meanwhile, it is also applicable to get the non-increasing returns to scale (NIRS) reference technology by adding the constant to $T$ (Ramanathan, 2005). In general, previous discussions were mainly based on strong disposable production possibility set, while VRS conditions could be properly combined with weak disposable production possible set as well (Zhou et al., 2007).

From the present literature listed in Table 1, we found that about a half of the studies in SD field assume the production possibility set as CRS, in spite of the VRS assumption might be more consistent with the actual production process (Ramanathan, 2005). The possible reason is that the CCR model has a better property than the BCC model, which is concretely embodied in the characteristic of the input-oriented radial efficiency is exactly the reciprocal of the output-oriented radial efficiency. As a result, under the CRS assumption, there will be no difference between input or output oriented DEA model. Furthermore, among the reviewed literature listed in Table 1, almost $17 \%$ of the studies were conducted under both the CRS and the VRS assumption. In this way, the scale efficiency of each DMU can be made further efforts on estimation. This method has been successfully applied by Pacudan and Guzman (2002) and Liu et al., (2017).

\subsubsection{Efficiency Measurement}

The efficiency of sustainable development measurements mainly includes input oriented, output oriented and undesirable output-oriented methods, and each one has its own advantages. In this study, we only introduce some widely used and representative methods in the study of SD.

Radial efficiency measurement is the most widely used method in the DEA model, which can adjust the input (output) in a certain proportion (Andersen \& Petersen, 1993). By combining radial efficiency measurement with different reference techniques, various DEA models can be obtained including BCC and CCR. If using $T_{e}$ and undesirable outputs efficiency to adjust the radial efficiency measurement, we will get a model as $\min \left\{\theta:\left(x_{0}, y_{0}, \theta u_{0}\right) \in T_{e}\right\}$, which can be used to measure the sustainability of a certain $\mathrm{DMU}_{0}$.

Non-radial efficiency measurement can help to adjust the different input (output) non-proportionally (Chen \& Sherman, 2004). A widely used non-radial efficiency measurement is the Russell efficiency $\left(\min \left\{\frac{1}{N} \sum_{n=1}^{N} \theta_{n}:\left(\theta x_{0}, y_{0}\right) \in T\right\}\right.$ ), where $\theta$ is a vector consisting of $\theta_{1}$ to $\theta_{n}$ (Färe et al., 1994). When giving the weights for $\theta_{n}(n=1,2, \ldots, n)$, the reference structure of each DMU can be obtained simultaneously (Sueyoshi et al., 2017). Because of the high identify ability; researchers are willing to use the non-radial efficiency measurement. Specifically, some studies adopted both radial and non-radial measurements, which tried to avoid the methodological bias in empirical research.

In addition to radial and non-radical efficiency measurements, slacks-based efficiency measurement is another way to measure DMU efficiency. Especially, the efficiency measurement on account of slack provides a more pragmatic index for evaluating environmental performance and has higher capacity of discernment (Hu \& Kao, 2007). This method can be directly modeled from the slacks in inputs (outputs), which is particularly useful in SD assessment.

In some studies, from the practical application aspect, directional distance function (DDF) efficiency measurement may be more appropriate. For example, in the process of sustainability assessment, DDF efficiency measurement can provide a more reasonable productivity index when we need to take both ideal and 
unsatisfactory outputs into consideration at the same time (Zanella et al., 2015). Additionally, in fact that the traditional radial efficiency method is another form for DDF (constrained by the specific direction); as such DDF is a more general concept.

\subsection{DEA Types}

\subsubsection{Preference}

Preference is a kind of binary relations which builds upon the alterative offers, representing the scheme's strengths and weaknesses judged by decision makers. Preference can be divided into rational preference and irrational preference. Pareto preference is a kind of rational preference, which is commonly adopted in DEA models. This part will discuss some other DEA models with rational preference.

The common method to bring in preference is to add appropriate weights restrictions into classical DEA models (CCR / BCC). Generally, weights restrictions are introduced through DEA models in multiplier form. Allen et al. (1997) pointed that weights restrictions can be primarily classified into four categories, as is shown in Table 2: (1) absolute weights restriction; (2) assurance regions of type I; (3) assurance regions of type II; (4) weight restrictions on virtual input and outputs. In addition, studies related to weights restrictions DEA model can be seen in Cook et al., (2005).

Table 2. The classification of weights restrictions

\begin{tabular}{lcc}
\hline \multicolumn{1}{c}{ Type } & \multicolumn{2}{c}{ Weight restriction } \\
\cline { 2 - 3 } & Weight restrictions on inputs & Weight restrictions on outputs \\
\hline Absolute weights restriction & $\delta_{i} \leq v_{i} \leq \tau_{i}$ & $\rho_{r} \leq \mu_{r} \leq \eta_{r}$ \\
Assurance regions of type I & $k_{i} v_{i}+k_{i+1} \nu_{i+1} \leq v_{i+2}$ & $w_{r} \mu_{r}+w_{r+1} \mu_{r+1} \leq \mu_{r+2}$ \\
Assurance regions of type II & $\alpha_{i} \leq v_{i} / \nu_{i+1} \leq \beta_{i}$ & $\theta_{r} \leq \mu_{r} / \mu_{r+1} \leq \phi_{r}$ \\
Weight restrictions on virtual input and & $\varphi_{i} \leq v_{i} x_{i j} / \sum_{i=1}^{m} v_{i} x_{i j} \leq \vartheta_{i}$ & $\gamma_{i} \leq \mu_{r}$ \\
outputs & & $\varpi_{i} \leq \mu_{r} y_{r j} / \sum_{r=1}^{s} \mu_{r} y_{r j} \leq \sigma_{r}$ \\
\hline
\end{tabular}

Note: $\left(\delta_{i}, \tau_{i}, \rho_{r}, \eta_{r}, k_{i}, w_{r}, \alpha_{i}, \beta_{i}, \theta_{r}, \gamma_{i}, \varphi_{i}, \vartheta_{i}, \varpi_{r}, \sigma_{r}\right)$ are pre-established constant.

Charnes et al. (1989) proposed the cone ratio restriction DEA model when decision makers' preference structure showed "cone preference". The model can be defined as follows:

$$
\operatorname{Max} \theta=\frac{\mu^{T} y_{0}}{v^{T} x_{0}}, \text { s.t. } v^{T} X-\mu^{T} Y \in K ; v \in V \backslash\{0\}, \mu \in U \backslash\{0\},
$$

Where $X=\left(x_{1}, x_{2}, \ldots x_{0}, \ldots, x_{n}\right)$ is a $m \times n$ matrix, $Y=\left(y_{1}, y_{2}, \ldots y_{0}, \ldots, y_{n}\right)$ is a $s \times n$ matrix, $V \in R_{+}^{m}$, $U \in R_{+}^{s}$ and Int $V \neq \varphi$, Int $U \neq \varphi$.

Subsequently, Charnes et al., (1990) conducted a further research on the optimal solution of cone ratio restriction DEA model. In addition, there are some other DEA models containing rational preference, including average preference DEA, matrix preference DEA and lexicographical order preference DEA.

In some cases, the preferred DEA model may be more suitable for SD practical applications. It is indicated that studies which conduct sustainability assessments tend to use preferred DEA models in Table 1. Examples of such studies include Reig-Martinez et al., (2011) and Khodakarami et al., (2015). The preference DEA model is to judge and weight the scheme's strengths and weaknesses, which is consistent with the purpose of SD analysis.

\subsubsection{Super Efficiency}

DEA efficient and inefficient DMUs can be distinguished by the efficiency value, but the key problem is that they can't rank the DEA efficient DMUs. During the process of efficiency evaluation, there are generally more than one DMUs on the production frontier simultaneously, these DMUs' efficiency values all equal to unit. In order to compensate for it and evaluate the real DMUs' efficiency, Super-efficient DEA model has been designed. Super efficiency DEA is a kind of comprehensive efficiency measurement, which can go a step further differentiate relative efficiency among DMUs (Chen \& Sherman, 2004). It has the resembling functional expression with CCR model and it can be described as following: 


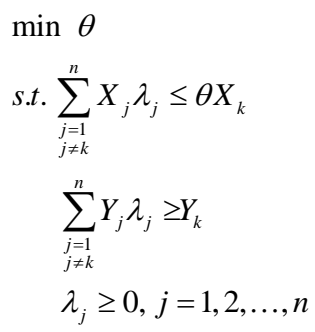

When calculating the relative efficiency of a DMU, the output $Y$ of the DMU and all $D_{M} U_{j}(j=1,2, \ldots, k)$ can be expressed by linear relation, not only the input and output of the $\mathrm{k}^{\text {th }}$ DMU in the traditional DEA model. In traditional DEA model, DMUs have the same efficiency value regardless of their efficiency level. However, in the super efficiency DEA model, this defect can be compensated by displaying different efficiency values of efficient DMUs. The efficient DMU's inputs can be proportionally increased with constant efficiency value, while the increase of input rate is the super efficiency value in super-efficient DEA model. For example, given the DMU's sustainability efficiency value is 1.1 , which means when increase $10 \%$ of the DMU's inputs, its sustainability efficiency value is still above one. Super efficiency value represents the maximum range while DMU maintains efficient in the premise.

\subsubsection{Network}

In the real process of economy activities, DMUs usually can be divided into two stages: the outputs generated in the first stage will become the second stage's inputs. Seiford and Zhu (1998) proposed a well-known two-stage case by using DEA model to measure the efficiency of each stage, without considering the relationship between different stages. In view of this, Kao and Hwang (2008) took the relationship comprehensively into account and constructed the corresponding model. Iribarren et al. (2010) put forward a method to measure integrated efficiency by weighted summation. Wang and Chin (2010) found that the integrated efficiency could also be measured by harmonic mean, and extended Kao and Huang's model to the VRS reference technology.

A drawback exists in the traditional DEA model is that the model can't involve the relationships between different DMUs in the organization. To compensate, Cook et al., (2010) proposed a method of network DEA, which could open the "black box" to evaluate the integrated DMUs' efficiency and the relative efficiency of each part in the organization. Hsieh and Lin (2010) studied the theoretical framework in a further step.

\subsection{Extensions}

The application of DEA described above is limited to cross-sectional analysis, such as comparing the efficiency of different regions at the same time. However, for SD studies, especially in the environmental performance evaluation field, it is of great significance for the investigating of productivity change in the production process.

Because of the nonparametric and formal time-series characteristics, Malmquist productivity index (MPI) and Luenberger productivity index (LPI) have been widely used for the comparing of different DMU performance over time. Based on the inputs and outputs, assuming that $\theta^{t}\left(x_{0}^{t}, y_{0}^{t}\right)$ and $\theta^{t+1}\left(x_{0}^{t}, y_{0}^{t}\right)$ are the $\mathrm{DMU}_{0}$ 's efficiency values at time period t for two different reference technologies. Specifically, in order to simplify the description, all the efficiency values are calculated based on the input-oriented. According to the study of Färe et al. (1994), $\mathrm{MPI}_{0}$ can be written as:

$$
M P I_{0}=\left[\frac{\theta^{t}\left(x_{0}^{t}, y_{0}^{t}\right)}{\theta^{t+1}\left(x_{0}^{t}, y_{0}^{t}\right)} \frac{\theta^{t}\left(x_{0}^{t+1}, y_{0}^{t+1}\right)}{\theta^{t+1}\left(x_{0}^{t+1}, y_{0}^{t+1}\right)}\right]^{1 / 2} \times \frac{\theta^{t+1}\left(x_{0}^{t+1}, y_{0}^{t+1}\right)}{\theta^{t}\left(x_{0}^{t}, y_{0}^{t}\right)}
$$

$\mathrm{MPI}_{0}>1, \mathrm{MPI}_{0}=1$ and $\mathrm{MPI}_{0}<1$ respectively indicate that during the period $\mathrm{t}$ to $\mathrm{t}+1$, the $\mathrm{DMU}_{0}$ 's productivity has experienced increased, unchanged, and decreased. The optimal frontier change between two periods reflects the change of production technology (the first part of $\mathrm{MPI}_{0}$ in Eq. (7)), and the change in relative efficiency reflects the efficiency change over time (the second part of $\mathrm{MPI}_{0}$ in Eq. (7)). Similarly, LPI can also be decomposed into two proportions to represent technology transformation and efficiency change respectively. Balk et al. (2008) discussed the exact relations between LPI and MPI, and they showed how the LPI transformed into the MPI. 
In order to correctly measure environmentally sensitive productivity growth, combining the merits of both Malmquist and Luenberger (integrates the concepts of the MPI and a directional distance function), Chung et al. (1997) proposed a Malmquist-Luenberger productivity index (hereafter, ML index). Additionally, from the distribution perspective, the ML index also provides another way to reallocate the weights of both desirable and undesired outputs. This is very useful and applicable in the real production process. As to the application scheme, sustainability assessment studies of productivity analysis usually tend to use ML rather than MPI and LPI indexes, as is exactly shown in Table 1. A representative example of such studies includes Oh (2010) and Juo et al. (2015). According to the above studies, even the ML index cannot directly reflect the welfare changes; it is helpful to provide a picture for the productivity change under the sustainable development regulations which are warmly concerned by the society.

Based on the productivity evaluation, in order to further understand the influence of each dimension in the sustainability assessment, sensitivity analysis is usually conducted. Charnes et al. (1992) firstly introduced sensitivity analysis by using DEA models. They assumed that, for a certain DMU in the certain production process, its inputs and outputs are synchronized in proportion while the other DMUs are unchanged.

Furthermore, Brannlund et al. (1998) pointed out that DEA is also a valid tool for studying the subject of emissions permit allocations in the SD topic. Recently, a decomposition technique has been proposed by using the distance function obtained in MPI estimation, which can be seen in the studies of Zhou and Ang (2008). By combining decomposition analysis with MPI, these studies decomposed assessment into technical efficiency and technical progress efficiency. Zhou and Ang (2008) named this technique the production theoretical decomposition analysis (PDA) As is shown in Table 1, PDA has already been applied in SD studies and it may provide a new direction for future research.

\subsection{Joint with Others}

In the field of sustainability assessment, literatures are abundant with articles which utilized a joint application of DEA and other methodologies. As showed in Table 1, the four most common methodologies are life cycle analysis (LCA), analytic hierarchy process (AHP), stochastic frontier analysis (SFA) and multi-criteria decision making (MCDM).

The integration of life cycle analysis and data envelopment analysis (LCA + DEA) to analyze the sustainable performance has been widely used. Of the studies listed in Table 1, about a quarter articles adopt this combination. As one of the representative articles, Egilmez et al. (2014) proposed the hierarchical LCA and DEA method to assess the American manufacturing sectors' sustainability performance. Iribarren and Rowe (2013) indicated that the key point to apply LCA and DEA to evaluate sustainable performance is the further explanation for LCA's results in DEA model.

Varieties of indicators in economic, social and environmental aspects usually need to be considered simultaneously in the process of sustainability assessment. The indicators have to be transformed into data in the first step, but the conversion process usually makes mistakes. Due to incorrect conversions, these indicators may lead to errors in the final result. In order to improve the accuracy of data conversion, the analytic hierarchy process and data envelopment analysis (AHP + DEA) is often integrated to analyze the sustainable performance. Take the research of Lee et al. (2010) as an example; they evaluated the sustainability of national hydrogen energy technology by combining fuzzy AHP and DEA. Of which, the fuzzy AHP was effectively applied to obtain accurate input and output data, and then the DEA model was used to evaluate the sustainability performance.

Stochastic frontier analysis (SFA) is an effective parametric mathematical optimization method that was originally proposed to measure a set of peer DMUs' efficiency and productivity. It is important to confirm the specific production function and select the appropriate variables before using SFA method. Stochastic frontier analysis and data envelopment analysis (SFA + DEA) are usually integrated to analyze the sustainable performance, which can be classified into two types generally. One is using SFA and DEA to evaluate the performance of the DMUs respectively, and then comparing the differences between the values of two methods. The other is integrating SFA and DEA into multi-stage model. For example, SFA was used based on the results of DEA (Huang et al., 2020).

In the process of performance evaluation, it is inevitable to choose unrealistic weights when different DMUs are identified. In order to solve this problem, Golany (1988) proposed a new theoretical method which combined DEA and MCDM (MCDM + DEA). And the approach has become much more popular these years. The utilization of MCDM has created a new way to solve the problems of ranking DMUs that exists in the conventional DEA models. 


\section{Application Scheme}

The review found that eco-efficiency performance evaluation accounts for the majority of the reviewed studies, followed by the applications of agriculture and supply chain management sustainability analysis.

Eco-efficiency is addressed by the OECD in 1998, defined as the efficiency of using ecological resources to meet the needs of human beings. There is a hot topic about eco-efficiency measurement in SD studies, because the increasing eco-efficiency value can be seen as an intermediate step towards the sustainability of the production process. Among the reviewed studies listed in Table 1, about a third of the articles dealt in this area. It might be the result of the increasing global attention about the environmentally sustainable development consciousness. Additionally, the outstanding advantage of DEA approach helps to construct a standardized and comprehensive environmental performance index. However, there seems to be an increasing tendency for using DEA in a single entity rather than a macro-level. Particularly, in the field of farm (José et al., 2012), company (Sueyoshi \& Wang, 2014), and industry (Egilmez \& Park, 2014), DEA approach has been widely applied.

Because of the growing global population, agriculture is needed to provide large quantities of food and fiber. As such, the productive activity of agriculture is a privileged area of sustainability analysis. In Table 1, it is clear that DEA has become an important tool for studying the sustainability of agricultural. Färe et al. (1985) was the first one to apply the DEA concept to investigate agriculture sustainable development. Then, Battese and Ceolli (1995) investigated the frontier function and agricultural economics to present their applications for measurement. Afterwards, Van et al., (2007) applied the DEA to solve the problem of economic, environmental and social sustainable development of agriculture. Table 1 also shows that the assessment of sustainability analysis at farm-level has been growing in much popularity in recent years.

Supply chain management was defined that "all those activities associated with transformation and flow of goods and service from raw material acquisition to end user's consumption, including their attendant information flows". Sustainable supply chain management (SSCM) has been widely concerned by scholars and practitioners in the past few years, and has become a method to improve economic, social and environmental performance at the same time. The evaluation of SSCM is a significant important task for any type of organizations. DEA is an appropriate evaluation method. Among the studies listed in Table 1, about a quarter deals with this area, and most of them appeared in the recent 10 years. There are two advantages of applying DEA method into the SSCM system. One is that the multi-input and multi-output complex system based on the DEA method can well describe the characteristics of the dynamic system. The other is that different type of DEA models can be used to evaluate the SSCM in different dimensions. Considering the importance of SCCM and the evaluation ability of DEA method under the combined action of multiple factors, DEA technology will play a more important role in SSCM research in the future.

Except for the previous application areas mentioned above, the DEA method has also been used to investigate the performance and efficiency of certain industrial sectors, for example, oil and coal industrial sector, food industrial sector, processing and manufacturing and motor vehicle industrial sector (Sueyoshi \& Goto, 2014). Additionally, exactly as the illustration by Khodakarami et al. (2015), DEA is an effective tool to study the distributive problems in sustainable development too.

\section{Guidelines and Outlook}

\subsection{Guidelines}

In the early stages of the SD concept, it has been obvious that variable selection and quantitative indicators played a vital role. However, due to many kinds of indicators, how to choose the appropriate variables among the many indicators for sustainability assessment is a problem. Customarily, possible inputs and outputs list that may be relevant to research should be firstly established. The second step is to further examine these input and output variables by means of preliminary judgment and statistical analysis. Thus, retaining the most appropriate and relevant indicators. Generally, in the empirical applications, the more the number of DMUs the better the evaluation effect will be. However, due to the data collect availability, in the process of variable determination, discrepancies in statistical quality and indicators make it very difficult to search data. According to a widely adopted rule, the number of DMUs should be more than two times the total number of inputs and outputs.

According to the review of the previous studies, many different types of DEA models are suitable for the efficiency evaluation. As a result, when scholars apply DEA method to study SD problems will inevitably encounter how to choose a specific DEA model problem. In a study, Ang (2004) pointed out that the four basic principles of the method selection are the theoretical foundation, adaptability, ease of use, and ease of result interpretation. Taking these into account, it is meaningful to systematically summarize and reconsider these 
principles, especially for the using of DEA in sustainable development research. Generally, in the evaluation of sustainable development field, the combination of traditional DEA and directional distance function method is more suitable for evaluating a DMU's production efficiency. Just as the description of Zhou et al. (2006), if a composite eco-efficiency index is expected, due to the better discrimination, the slacks-based efficiency measure should be adopted. Besides, if researchers try to identify the sustainability performance, the non-parametric MPI and LPI indexes based on the CCR model are strongly recommended.

\subsection{Outlook}

The reason we study the performance of sustainable development is to balance the complex interconnections between the environment, economy, and society. Specifically, for an enterprise, the enterprise has to balance the distribution between production efficiency and environmental efficiency during the production process. As a result, how to formulate a suitable distribution mechanism, stipulate the distribution principles and harmonize the performance and fairness are all required to explore in a further step.

Conventionally, the DEA model applied in sustainable development doesn't consider the inner structure and external relationship of DMUs. Nevertheless, the different DMUs are related to each other in the real production process, which need to analyze the inner "black box" of DMUs. Although some researchers and models have focused on this aspect (as is shown in 3.1.5), the studies and the achievements are still not enough. For the complexity analysis of the SD internal network, it is still necessary to study the inherent structure and characteristics of the SD method.

\section{Conclusions}

DEA method has been applied to the field of sustainable development by a large number of professionals and has achieved abundant research results, however, there still has no systematic literature review for the future reference. Therefore, this article provides a comprehensive and systematic review of previous research results to fill this gap in SD, which will facilitate future research.

In terms of mathematical methods, we concluded that DEA models with the reference technology of constant return to scale and the radial efficiency measurements are the most widely applied in SD field. Scholars prefer to take desirable outputs and undesirable outputs into account, and tend to use the DDF efficiency of the environment DEA method in the area of sustainable development research. If the performance of the DMUs changes with time, the DEA model usually deals with different variants in conjunction with MPI, ML, and PDA methods. At the same time, we found that scholars are increasingly concerned about the combination of DEA and other methods, such as LCA, SFA, AHP and MCDM. In terms of empirical applications, we found that studies associated with eco-efficiency performance evaluation are shown the most, followed by the applications of agriculture and supply chain management sustainability analysis.

According to the literature review and analysis, we have compiled some guidelines and outlook for the DEA method used in the research of sustainable development. Sustainable development has become a global research hotspot, which involves all aspects of economy, environment and society. In addition, DEA method carries out relative efficiency evaluation according to a number of inputs and outputs. We have reasons to believe that DEA method will play an increasingly important role in the field of sustainable development.

\section{Declarations}

Funding: This study was supported by National Natural Science Foundation of China (no. 71904059) and Natural Science Foundation of the Jiangsu Higher Education Institutions of China (no.19KJB580007).

Conflicts of interest/Competing interests: The authors declare no conflict of interest.

Availability of data and material: Not applicable

Code availability: Not applicable

Authors' contributions: Jun Miao, Anqi Qiu and Liu Xiao wrote the paper; Houxue Xia and Jin Chen gave guidance and improved the paper quality. All authors contributed substantially to the work reported.

\section{Acknowledgment}

Authors are grateful to the financial support from the National Natural Science Foundation of China (no. 71904059) and Natural Science Foundation of the Jiangsu Higher Education Institutions of China (no.19KJB580007).

\section{References}

Abay, C., Miran, B., \& Gunden, C. (2004). An analysis of input use efficiency in tobacco production with respect 
to sustainability: the case study of Turkey. Journal of Sustainable Agriculture, 24(3), 123-143. https://doi.org/10.1300/J064v24n03_09

Aldeseit, B. (2013). Measurement of Scale Efficiency in Dairy Farms: Data Envelopment Analysis (DEA) Approach. Journal of Agricultural Science, 5(9), 37-43. https://doi.org/10.5539/jas.v5n9p37

Allen, R., Athanassopoulos, A., Dyson, R. G., \& Thanassoulis, E. (1997). Weights restrictions and value judgements: Evolution, development and future directions. Annals of Operations Research, 73, 13-34. https://doi.org/10.1023/A:1018968909638

Andersen, P., \& Petersen, N. C. (1993). A procedure for ranking efficient Units in data envelopment analysis. Management Science, 39(1), 1261-1264. https://doi.org/10.1287/mnsc.39.10.1261

André, F. J., Herrero, I., \& Riesgo, L. (2010). A modified DEA model to estimate the importance of objectives with an application to agricultural economics. Omega, 38(5), 371-382. https://doi.org/10.1016/j.omega.2009.10.002

Ang, B.W. (2004).Decomposition analysis for policymaking in energy: Which is the preferred method? Energy Policy, 32, 1131-1139. https://doi.org/10.1016/S0301-4215(03)00076-4

Arabi, B., Susila, M., \& Ali, E. (2014). Power industry restructuring and eco-efficiency changes: A new slacks-based model in Malmquist-Luenberger Index measurement. Energy Policy, 68, 132-145. https://doi.org/10.1016/j.enpol.2014.01.016

Balk, B. M., Färe, R., Grosskopf, S., \& Margaritis, D. (2008). Exact relations between Luenberger productivity indicators and Malmquist productivity indexes. Economic Theory, 35(1), 187-190. https://doi.org/10.1007/s00199-007-0228-5

Battese, G. E., \& Coelli T. K. (1995). A model for technical inefficiency effects in a stochastic frontier production function for panel data. Empirical Economics, 89(20), 325-332. https://doi.org/10.1007/BF01205442

Becker, G. S., \& Mulligan, C. B. (1997). The endogenous determination of time preference. The Quarterly Journal of Economics, 112(3), 729-758. https://doi.org/10.1162/003355397555334

Brannlund, R., Chung, Y., Färe, R., \& Grosskopf, S. (1998). Emissions trading and profitability: The Swedish pulp and paper industry. Environmental and Resource Economics, 12, 345-356. https://doi.org/10.1023/A:1008285813997

Callens, I., \& Tyteca, D. (1999). Towards indicators of sustainable development for firms: A productive efficiency perspective. Ecological Economics, 28(1), 41-53. https://doi.org/10.1016/S0921-8009(98)00035-4

Charnes, A., Cooper W. W., \& Rhodes, E. (1978). Measuring the efficiency of decision making units. European Journal of Operational Research, 2(6), 429-444. https://doi.org/10.1016/0377-2217(78)90138-8

Charnes, A., Cooper, W. W., Huang, Z., \& Sun, D. (1990). Polyhedral cone-ratio DEA models with an illustrative application to large commercial banks. Journal of Econometrics, 46(1/2), 73-91. https://doi.org/10.1016/0304-4076(90)90048-X

Charnes, A., Cooper, W. W., Wei, Q. L., \& Huang, Z. M. (1989). Cone Ratio Data Envelopment Analysis and Multi-Objective Programming. International Journal of Systems Science, 20, 1099-1118. https://doi.org/10.1080/00207728908910197

Charnes, A., Haag, S., Jaska, P., \& Semple, J. (1992). Sensitivity of efficiency classifications in the additive model of data envelopment analysis. International Journal of Systems Science, 23, 789-798. https://doi.org/10.1080/00207729208949248

Chen, Y., \& Sherman, H. D. (2004). The benefits of non-radial vs. radial super-efficiency DEA: an application to burden-sharing amongst NATO member nations. Socio-Economic Planning Sciences, 38(4), 307-320. https://doi.org/10.1016/j.seps.2003.10.007

Chung, Y. H., Färe, R., \& Grosskopf, S. (1997). Productivity and undesirable outputs: A directional distance function approach. Journal of Environmental Management, 51, 229-240. https://doi.org/10.1006/jema.1997.0146

Cook, W. D., Chai, D., Doyle, J., \& Green, R. H. (2005). Evaluating power plant efficiency: A hierarchical model. Computers \& Operations Research, 32, 813-823. https://doi.org/10.1016/j.cor.2003.08.019 
Cook, W. D., Liang, L., \& Zhu, J. (2010). Measuring performance of two-stage network structures by DEA: a review and future perspective. Omega, 38, 423-430. https://doi.org/10.1016/j.omega.2009.12.001

Dong, F., Mitchell, P., Knuteson, D., Wyman, J., Bussan, A., \& Conley, S. (2016). Assessing sustainability and improvements in U.S. Midwestern soybean production systems using a PCA-DEA approach. Renewable Agriculture and Food System, 31(6), 524-539. https://doi.org/10.1017/S1742170515000460

Donghyun, O., \& Almas, H. (2010). A Sequential Malmquist-Luenberger Productivity Index: Environmental Sensitive Productivity Growth Considering the Progressive Nature of Technology. Energy Economics, 32(6), 1345-1355. https://doi.org/10.1016/j.eneco.2010.09.003

Egilmez, G., \& Park, Y. S. (2014). Transportation related carbon, energy and water footprint analysis of US manufacturing: an eco-efficiency assessment. Transportation Research Part D: Transport and Environment, 32, 143-159. https://doi.org/10.1016/j.trd.2014.07.001

Egilmez, G., Kucukvar, M., \& Tatari, O. (2013). Sustainability assessment of US manufacturing sectors: an economic input output-based frontier approach. Journal of Cleaner Production, 53, 91-102. https://doi.org/10.1016/j.jclepro.2013.03.037

Egilmez, G., Kucukvar, M., Tatari, O., \& Bhutta, M. K. S. (2014). Supply chain sustainability assessment of the U.S. food manufacturing sectors: a life cycle-based frontier approach. Resources, Conservation and Recycling, 82, 8-20. https://doi.org/10.1016/j.resconrec.2013.10.008

Ewert, F., Rounsevell, M. D. A., Reginster, I., Metzger, M. J., \& Leemans, R. (2005). Future scenarios of European agricultural land use: II. Estimating changes in crop productivity. Agriculture, Ecosystems \& Environment, 107(2), 101-116. https://doi.org/10.1016/j.agee.2004.12.003

Färe, R., Grosskopf, S., \& Logan, J. (1985). The relative performance of publicly-owned and privately-owner electric utilities. Journal of Public Economics, 26, 89-106. https://doi.org/10.1016/0047-2727(85)90040-4

Färe, R., Grosskopf, S., \& Pasurka Jr., C. A. (2001). Accounting for air pollution emissions in measures of state manufacturing productivity growth. Journal of Regional Science, 41, 381-409. https://doi.org/10.1111/0022-4146.00223

Färe, R., Grosskopf, S., Lindgren, B., \& Roos, P. (1994). Productivity developments in Swedish hospitals: A Malmquist output index approach. Springer Netherlands, 45(2), 227-235. https://doi.org/10.1007/978-94-011-0637-5_13

Fried, H. O., Lovell, C. A. K., Schmidt, S. S., \& Yaisawarny, S. (2002). Accounting for environmental effects and statistical noise in data envelopment analysis. Journal of Productivity Analysis, 17, 157-174. https://doi.org/10.1023/A:1013548723393

Gerdessen, J. C., \& Pascucci, S. (2013). Data envelopment analysis of sustainability indicators of European agricultural systems at regional level. Agricultural Systems, 118, 78-90. https://doi.org/10.1016/j.agsy.2013.03.004

Golany, B. (1988). An interactive MOLP procedure for the extension of DEA to effectiveness analysis. J. Oper. Res. Soc., 39(8), 725-734. https://doi.org/10.1057/jors.1988.127

Gomes, E. G., Soares de Mello, J. C. C. B., Souza, G. S., Angulo Meza, L., \& Mangabeira, J. A. C. (2009). Efficiency and sustainability assessment for a group of farmers in the Brazilian Amazon. Annals of Operations Research, 169, 167-181. https://doi.org/10.1007/s10479-008-0390-6

Gutierrez, E., \& Lozano, S. (2009). Data envelopment analysis of multiple response experiments. Applied Mathematical Modelling, 34(5), 1139-1148. https://doi.org/10.1016/j.apm.2009.08.001

Gutiérrez, Y., Adenso-Díaz, B., \& Lozano, S. (2009). Eco-Efficiency of Electric and Electronic Appliances: A Data Envelopment Analysis (DEA). Environmental Modeling \& Assessment, 14(4), 439-447. https://doi.org/10.1007/s10666-007-9134-2

Hoang, V. N., \& Alauddin, M. (2012). Input-orientated data envelopment analysis framework for measuring and decomposing economic, environmental and ecological efficiency: an application to OECD agriculture. Environmental\& Resource Economics, 51(3), 431-452. https://doi.org/10.1007/s10640-011-9506-6

Houshyar, E., Azadi, H., Almassi, M., Davoodi, M. J. S., \&Witlox, F. (2012). Sustainable and efficient energy consumption of corn production in Southwest Iran: Combination of multi-fuzzy and DEA modeling. Energy, 44(1), 672-681. https://doi.org/10.1016/j.energy.2012.05.025 
Hsieh, L. F., \& Lin, L. H. (2010). A performance evaluation model for international tourist hotels in Taiwan: an application of the relational network DEA. Intern J Hosp Manag., 29, 14-24. https://doi.org/10.1016/j.ijhm.2009.04.004

Hu, J. L., \& Kao, C. H. (2007). Efficient energy-saving targets for APEC economies. Energy Policy, 35, 373-382. https://doi.org/10.1016/j.enpol.2005.11.032

Iribarren, D., \& Vázquez-Rowe, I. (2013). Is labor a suitable input in LCA + DEA studies? Insights on the combined use of economic, environmental and social parameters. Social Sciences, 2, 114-130. https://doi.org/10.3390/socsci2030114

Iribarren, D., Vázquez-Rowe, I., Moreira, M. T., \& Feijoo, G. (2010). Further potentials in the joint implementation of life cycle assessment and data envelopment analysis. Science of the Total Environment, 408, 5265-5272. https://doi.org/10.1016/j.scitotenv.2010.07.078

José, A., Gómez, L., Andrés, J., Picazo-Tadeo, \& Reig-Martínez, E. (2012). Eco-efficiency assessment of olive farms in Andalusia. Land Use Policy, 29(2), 395-406. https://doi.org/10.1016/j.landusepol.2011.08.004

Juo, J. C., Lin, Y. H., \& Chen, T. C. (2015). Productivity change of Taiwanese farmers' credit unions: a nonparametric metafrontier Malmquist-Lunenberger productivity indicator. Central European Journal of Operations Research, 23(1), 125-147. https://doi.org/10.1007/s10100-013-0307-6

Kao, C., \& Hwang, S. N. (2008). Efficiency decomposition in two-stage data envelopment analysis: An application to non-life insurance companies in Taiwan. European Journal of Operational Research, 185(1), 418-429. https://doi.org/10.1016/j.ejor.2006.11.041

Khodakarami, M., Shabani, A., Saen, R. F., \& Azadi, M. (2015). Developing distinctive two-stage data envelopment analysis models: An application in evaluating the sustainability of supply chain management. Measurement, 70, 62-74. https://doi.org/10.1016/j.measurement.2015.03.024

Korhonen, P. J., \& Luptacik, M. (2004). Eco-efficiency analysis of power plants: An extension of data envelopment analysis. European Journal of Operational Research, 154, 437-446. https://doi.org/10.1016/S0377-2217(03)00180-2

Lee, S. K., Mogi, G., Sang, K. L., Hui, K. S., \& Kim, J. W. (2010). Econometric analysis of the R\&D performance in the national hydrogen energy technology development for measuring relative efficiency: The fuzzy AHP/DEA integrated model approach. International Journal of Hydrogen Energy, 35(6), 2236-2246. https://doi.org/10.1016/j.ijhydene.2010.01.009

Li, M. (2010). Decomposing the change of CO2 emissions in China: a distance function approach. Ecological Economics, 70, 77-85. https://doi.org/10.1016/j.ecolecon.2010.07.034

Liu, X., Zhou, D. Q., Zhou, P., \& Wang, Q. W. (2017). What drives CO2 emissions from China's civil aviation? An exploration using a new generalized PDA method. Transportation Research Part A: Policy and Practice, 99, 30-45. https://doi.org/10.1016/j.trb.2017.01.005

Louhichi, K., Kanellopoulos, A., Janssen, S., Flichman, G., Blanco, M., Hengsdijk, H., ... Van Ittersum, M. (2010). FSSIM, a bio-economic farm model for simulating the response of EU farming systems to agricultural and environmental policies. Agricultural Systems, 103, 585-597. https://doi.org/10.1016/j.agsy.2010.06.006

Mahdiloo, M., Saen, R. F., \& Lee, K. H. (2015). Technical, environmental and eco-efficiency measurement for supplier selection: An extension and application of data envelopment analysis. Int. J. Prod. Econ., 168, 279-289. https://doi.org/10.1016/j.ijpe.2015.07.010

Munksgaard, J., Wier, M., Lenzen, M., \& Dey, C. (2008). Using input-output analysis to measure the environmental pressure of consumption at different spatial levels. Journal of Industrial Ecology, 9(1/2), 169-85. https://doi.org/10.1162/1088198054084699

Oh, D. (2010). A metafrontier approach for measuring an environmentally sensitive productivity growth index. Energy Econ, 32(1), 146-157. https://doi.org/10.1016/j.eneco.2009.07.006

Pacudan, R., \& de Guzman, E. (2002). Impact of energy efficiency policy to productive efficiency of electricity distribution industry in the Philippines. Energy Economics, 24, 41-54. https://doi.org/10.1016/S0140-9883(01)00085-8

Ramanathan, R. (2005). An analysis of energy consumption and carbon dioxide emissions in countries of the Middle East and North Africa. Energy, 30, 2831-2842. https://doi.org/10.1016/j.energy.2005.01.010 
Reig-Martınez, E., \& Gómez-Limón, J. A., (2011). Picazo-Tadeo, A. J. Ranking farms with a composite indicator of sustainability. Agricultural Economics, 42(5), 561-575. https://doi.org/10.1111/j.1574-0862.2011.00536.x

Reinhard, S., Lovell, C. A. K., \& Thijssen, G. J. (2000). Environmental efficiency with multiple environmentally detrimental variables; estimated with SFA and DEA. European Journal of Operational Research, 121(2), 287-303. https://doi.org/10.1016/S0377-2217(99)00218-0

Sarkis, J., \& Talluri, S. (2011). Ecoefficiency measurement using data envelopment analysis: research and practitioner issues. Journal of Environmental Assessment Policy and Management, 6(1), 1464-3332.

Seiford, L. M., \& Zhu, J. (1998). Identifying excesses and deficits in Chinese industrial productivity (1953-1990): A weighted data envelopment analysis approach. OMEGA, International Journal of Management Science, 26, 279-296. https://doi.org/10.1016/S0305-0483(98)00011-5

Senante, M., Gémar, G., Gómez, T., Caballero, R., \& Sala-Garrido, R. (2016). Eco-efficiency assessment of wastewater treatment plants using a weighted Russell directional distance model. Journal of Cleaner Production, 137(1), 1066-1075. https://doi.org/10.1016/j.jclepro.2016.07.057

Senante, M., Gómez, T., Garrido-Baserba, M., Caballero, R., \& Sala-Garrido, R. (2014). Assessing the sustainability of small wastewater treatment systems: a composite indicator approach. Sci Total Environ., 497, 607-617. https://doi.org/10.1016/j.scitotenv.2014.08.026

Sueyoshi, T., \& Goto, M. (2014). Investment strategy for sustainable society by development of regional economies and prevention of industrial pollutions in Japanese manufacturing sectors. Energy Economics, 42, 299-312. https://doi.org/10.1016/j.eneco.2014.01.001

Sueyoshi, T., \& Goto, M. (2015). DEA environmental assessment on coal-fired power plants in U.S. north-east region by DEA non-radial measurement. Energy Economics, 50, 125-139. https://doi.org/10.1016/j.eneco.2015.04.016

Sueyoshi, T., \& Wang, D. (2014). Radial and non-radial approaches for environmental assessment by data envelopment analysis: corporate sustainability and effective investment for technology innovation. Energy Economics, 45, 537-551. https://doi.org/10.1016/j.eneco.2014.07.024

Sueyoshi, T., \& Yuan, Y. (2015). China's regional sustainability and diversity: DEA environmental assessment on economic development and air pollution. Energy Economics, 49, 239-256. https://doi.org/10.1016/j.eneco.2015.01.024

Sueyoshi, T., \& Yuan, Y. (2016). Marginal Rate of Transformation and Rate of Substitution measured by DEA environmental assessment: Comparison among European and North American nations. Energy Economics, 56, 270-287. https://doi.org/10.1016/j.eneco.2016.01.017

Sueyoshi, T., Li, A., \& Gao, Y. (2018). Sector Sustainability on Fossil Fuel Power Plants across Chinese Provinces: Methodological Comparison among Radial, Non-radial and Intermediate Approaches under Group Heterogeneity. Journal of Cleaner Production, 187, 819-829.

https://doi.org/10.1016/j.jclepro.2018.03.216

Sueyoshi, T., Yuan, Y., Li, A., \& Wang, D. (2017). Methodological Comparison among Radial, Non-radial and Intermediate Approaches for DEA Environmental Assessment. Energy Economics, 67, 439-453. https://doi.org/10.1016/j.eneco.2017.07.018

Tatari, O., \& Kucukvar, M. (2012). Eco-efficiency of construction materials: a data envelopment analysis. Journal of Construction Engineering and Management, 138(6), 733-741. https://doi.org/10.1061/(ASCE)CO.1943-7862.0000484

Van Calker, K. J., Berentsen, P. B. M., De Boer, I. J. M., Giesen, G. W. J., \& Huirne, R. B. M. (2007). Modelling worker physical health and societal sustainability at farm level: An application to conventional and organic dairy farming. Agricultural Systems, 94(2), 205-219. https://doi.org/10.1016/j.agsy.2006.08.006

Vandaele, N., \& Decouttere, C. (2013). Sustainable R\&D portfolio assessment. Decision Support Systems, 54(4), 1521-1532. https://doi.org/10.1016/j.dss.2012.05.054

Wang, Y. M., \& Chin, K. S. (2010). A neutral DEA model for cross-efficiency evaluation and its extension. Expert Systems with Applications, 37, 3666-3675. https://doi.org/10.1016/j.eswa.2009.10.024

Zanella, A., Camanho, A. S., \& Dias, T. G. (2015). The assessment of cities' livability integrating human wellbeing and environmental impact. Annals of Operations Research, 226(1), 695-726.

https://doi.org/10.1007/s10479-014-1666-7 
Zhou, P., \& Ang, B. W. (2008). Linear programming models for measuring economy-wide energy efficiency performance. Energy Policy, 36, 2911-2916. https://doi.org/10.1016/j.enpol.2008.03.041

Zhou, P., Ang, B. W., \& Poh, K. L. (2006). Slacks-based efficiency measures for modeling environmental performance. Ecological Economics, 60, 111-118. https://doi.org/10.1016/j.ecolecon.2005.12.001

Zhou, P., Ang, B. W., \& Poh, K. L. (2008). Measuring environmental performance under different environmental DEA technologies. Energy Economics, 30(1), 1-14. https://doi.org/10.1016/j.eneco.2006.05.001

Zhou, P., Poh, K. L., \& Ang, B. W. (2007). A non-radial DEA approach to measuring environmental performance. European Journal of Operational Research, 178, 1-9. https://doi.org/10.1016/j.ejor.2006.04.038

Zhu, J. (1996). Data envelopment analysis with preference structure. Journal of the Operational Research Society, 47, 136-150. https://doi.org/10.1057/jors.1996.12

Zhu, Z., Wang, K., \& Zhang, B. (2014). Applying a network data envelopment analysis model to quantify the eco-efficiency of products: a case study of pesticides. Journal of Cleaner Production, 69, 67-73. https://doi.org/10.1016/j.jclepro.2014.01.064

\section{Copyrights}

Copyright for this article is retained by the author(s), with first publication rights granted to the journal.

This is an open-access article distributed under the terms and conditions of the Creative Commons Attribution license (http://creativecommons.org/licenses/by/4.0/). 